IRA-International Journal of Management \& Social Sciences

ISSN 2455-2267; Vol.06, Issue 01 (2017)

Pg. no. 13-23

Institute of Research Advances

http://research-advances.org/index.php/RAJMSS

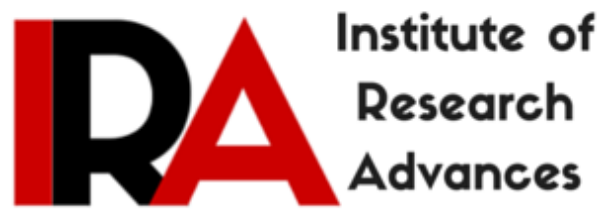

\title{
Perspectives of Decentralized Powerloom Industry in India- An Empirical Analysis
}

\section{Dr. Basavraj S Kudachimath ${ }^{1}$}

Associate Professor, Visvesvaraya Technological University, Belagavi, India.

Shashidhar S Mahantshetti ${ }^{2}$

Research Scholar, Angadi Institute of Technology \& Management, Belagavi, India.

Type of Review: Peer Reviewed.

DOI: http://dx.doi.org/10.21013/jmss.v6.n1.p3

\section{How to cite this paper:}

Kudachimath, B., \& Mahantshetti, S. (2017). Perspectives of Decentralized Powerloom Industry in India- An Empirical Analysis. IRA-International Journal of Management \& Social Sciences (ISSN 2455-2267), 6(1), 13-23. doi:http://dx.doi.org/10.21013/jmss.v6.n1.p3

(C) Institute of Research Advances

\section{(c) EY-NC}

This work is licensed under a Creative Commons Attribution-Non Commercial 4.0 International License subject to proper citation to the publication source of the work.

Disclaimer: The scholarly papers as reviewed and published by the Institute of Research Advances (IRA) are the views and opinions of their respective authors and are not the views or opinions of the IRA. The IRA disclaims of any harm or loss caused due to the published content to any party. 


\section{ABSTRACT}

Decentralized powerloom sector in Indi has always occupied a prominent place in the economic spheres of India. Present study pertains to the decentralized powerloom sector in India and its various dimensions. The data obtained from various reliable sources such as ministry of textiles, fibre2fashion, powerloom development and export promotion council and RBI reports were subjected to time series analysis and regression analysis. The results indicated there is an upward trend towards growth in terms of employment generation and production. The results pointed towards the decentralized sectors' enormous potential to generate employment to both skilled and unskilled human resource in the country. The regression analysis showed a positive relation between the sector and GDP. In the light of the potentiality of the sector, suggestions have been put forth for harnessing the potential of the sector and make aid the country to be the most preferred source for clothing needs of the world.

Keywords: Decentralized powerloom sector, regression analysis, time series analysis

\section{Introduction}

India's textile industry is the second largest sector after agricultural sector in India in terms of employment generation. The textile industry has been a panacea for a large pool of unskilled labour in India, as it has accommodated a significant portion of unskilled human resource in India. The textile industry in India comprises of the mill sector, the handloom sector and the powerloom sector. India is the largest exporter of yarn in the International market and has $25 \%$ share in world cotton yarn exports. Powerloom sector is predominantly an unorganized sector and is referred to as decentralized powerloom sector. Yet, the unorganized sector has been contributing to $50 \%$ of the clothing needs of the country. Powerloom sector is considered to be a branched out sector of the handloom sector. The decentralized powerloom sector has been providing employment to more than 60 lakh people, both skilled and unskilled workforce in India. Technology advancement has been both a boon and bane to the weaving community in the powerloom sector. Improvisation in the sector has spiraled the productivity and efficiency of the weavers. At the same time, those who have not been able to catch up with the evolution, owing to financial and technological constraints has raised the concerns of imbalanced development of the sector. Moreover the golden goose of India's textile industry is in serious threat of being in doldrums. Handloom and powerloom industries over the years in Indian scenario have gained cultural significance. It is high time that the stakeholders bring about systemic reforms are initiated to not only rescue but revive the industry.

\section{Review of Literature}

Arif Anjum and D. V. Thakor in 2011 in their research on "An analytical study of the functioning and the problems of the powerloom industry in Maharashtra with special reference to Malegaon district, Nashik observed that the decentralized sector has inherent advantages to transform itself into a progressive sector post WTO regime. The industry should not only focus on the technological aspects but also should upgrade their marketing strategies

Summaiya R Shaikh \& Satish Dulange in 2013 commented in their research "A study on factors affecting productivity of powerloom Industries" that factors such as infrastructure, plant and equipment factor do not have much impact on productivity. Rather human factor and technological factors are the two most important factors which have impact on productivity of powerloom output.

Jnana Ranjan Prusty and Sambit Mallick in 2013 in their study "A sociological study of siminoi powerloom cluster in Odisha" observed that Cotton prices are very dynamic due to change in the size of crop. The uncertainty with the availability of cotton and fluctuating prices have pushed the powerloom sector into a sorry plight. Governments in other countries have been supporting the cotton growers by 
means of support price, which is not happening in India. Dr. Saravanan, K. A Ramya In their research in 2015 , concluded that shortage of power, scarcity of raw materials, lack of government support and changes in the climate are some of the major issues with the powerloom sector. Muthu Yuvraj in his study has examined the growth of powerloom sector in India from 2006-2013. The study showed that the sector has seen a considerable growth for the duration. Anirudha P Kamble, Dr A G Suryavanshi in their research indicated that year 2007 - 08 had maximum growth percentage which saw $5.8 \%$ growth in powerloom installation in India, whereas from 2009 - 2010 the powerloom installation growth has wavered considering the base year 2007 - 2008. $58.26 \%$ is average percentage of powerloom cloth production over total cloth production in India. http://www.tusharmehta.com/publish_train/data_analysis/16.htm

\section{Research Methodology}

The current study is a descriptive study and draws on the secondary resources such as research journals, books, and websites. An attempt has been made to study the various reports of the powerloom sector. Data of decentralized powerlooms for the last ten years ranging from 2006 to 2016 was collected. Annual reports and reports from the ministry of textiles have also been referred to arrive at the conclusion. The data collected was subjected to regression analysis and karl pearson coefficient of correlation. Trend analysis was carried out to get a vague idea about what the future holds for the sector.

\section{Objectives of the study}

a) To study the overall scenario of decentralized powerloom sector in India.

b) To study the future trends in the decentralized powerloom sector.

c) To study the relationship between growth, employment and production of decentralized powerloom sector.

d) To suggest measures to actualize the potential of the sector, and aid India in making a preferred destination for clothing needs of the world.

\section{Research Findings}

\section{Data Analysis \& Discussion}

\section{a) Overview of the decentralized powerloom industry in India}

The Table.1, reveals that the number of decentralized powerloom units has been increasing over the last 10 years. There are presently close to 5 lakh powerloom units. In correspondence with the number of units, number of looms has also increased. There are over 25 lakh looms which includes both shuttles and shuttle looms. The sector has witnessed considerable growth over the last ten years. Nonetheless, there was a slight stagnation between 2009 t0 2012 owing to infrastructure scarcities and fierce competition from the mill sector. The sector has been providing employment opportunities to more than 6 million skilled and unskilled human resource in India. As on date, the powerloom sector contributes $58 \%$ of the clothing needs of the country. Decentralized powerloom sector produced more than 38,000 million square meters for the fiscal year 2015-16. The sector has also been on crossroads towards adopting modern technology. With the advent of modern shuttles looms, there is bound to be a further push towards the growth of the sector.

\section{b) Future trends in the decentralized powerloom sector}

Analyzing sectoral trends provides a crisp representation of data which enables us to make predictions about what may happen in the future based on historical data. Various methods are available to analyze the data. Regression analysis with time series method has been employed to get an understanding of the linearity between the dependent and independent variables. Further to understand the future trends, extrapolation has been carried out. A simple linear trend is represented by the equation $y=a+b x$ where y a 
dependent variable is predicted by the independent variable (x) over a period of time and (a) being constant.

The regression coefficients for the past 10 years and powerloom units, powerloom workers, powerloom production shows a positive relationship. From figure 1 it is evident that there is an upward trend for growth in powerloom units. Due to the flexibility in operating a loom and its advantages over other sources of production, there is consistent increase in the number of decentralized powerloom units in the country. The growth trend predicts a consistent growth in the future as well.

Figure 2, shows a similar linear trend for the employment scenario in the powerloom sector. Though the trend predicts increase in employment generation, it needs to be seen whether the up gradation in technology will have any negative influence on the employment generation front.

Figure 3, indicates that the growth in the looms has a very strong linear trend. Trend line and the actual growth in number of looms almost coincide. Today the country houses a staggering 25 lakh looms across the country. With the ever increasing demand for the clothing needs, there appears to be growing phase for the number of powerlooms.

Figure 4, shows a slightly wavering pattern in term of production from the powerloom sector. From 2009 to 2012, the growth was sluggish and this possibly could be explained by the global recession and competitive forces working more aggressively.

c) Relationship between growth, employment and production of powerloom sector:

1. Correlation between No. of powerlooms \& workers SPSS Table 1.

\begin{tabular}{|c|c|c|c|}
\hline \multicolumn{4}{|c|}{ Correlations } \\
\hline & & $\begin{array}{c}\text { no of } \\
\text { powerloo } \\
\text { ms }\end{array}$ & $\begin{array}{c}\text { WORKER } \\
\mathrm{S}\end{array}$ \\
\hline no of powerlooms & $\begin{array}{l}\text { Pearson Correlation } \\
\text { Sig. (2-tailed) } \\
\mathrm{N}\end{array}$ & $\begin{array}{r}1.000 \\
10 \\
\end{array}$ & $\begin{array}{c}.999^{\star} \\
.000 \\
10 \\
\end{array}$ \\
\hline WORKERS & $\begin{array}{l}\text { Pearson Correlation } \\
\text { Sig. (2-tailed) } \\
\mathrm{N}\end{array}$ & $\begin{array}{c}.999^{\star \star} \\
.000 \\
10\end{array}$ & $\begin{array}{r}1.000 \\
10\end{array}$ \\
\hline
\end{tabular}

${ }^{\star \star}$. Correlation is signific ant at the 0.01 level (2-tailed).

\section{Correlations between Production on powerlooms \& worker} SPSS Table 2

\begin{tabular}{|c|c|c|c|}
\hline \multicolumn{4}{|c|}{ Correlations } \\
\hline & & $\begin{array}{l}\text { productio } \\
\text { non } \\
\text { powerloo } \\
\text { ms }\end{array}$ & $\begin{array}{c}\text { WORKER } \\
S\end{array}$ \\
\hline $\begin{array}{l}\text { production on } \\
\text { powerlooms }\end{array}$ & $\begin{array}{l}\text { Pearson Correlation } \\
\text { Sig. (2-tailed) } \\
\mathrm{N}\end{array}$ & $\begin{array}{r}1.000 \\
10 \\
\end{array}$ & $\begin{array}{r}.858^{\star} \\
.001 \\
10\end{array}$ \\
\hline WORKERS & $\begin{array}{l}\text { Pearson Correlation } \\
\text { Sig. (2-tailed) } \\
N\end{array}$ & $\begin{array}{c}.858^{* *} \\
.001 \\
10\end{array}$ & $\begin{array}{r}1.000 \\
10\end{array}$ \\
\hline
\end{tabular}

**. Correlation is significant at the 0.01 level (2-tailed). 


\section{Correlation between GDP and Production of Powerloom SPSS TABLE 3}

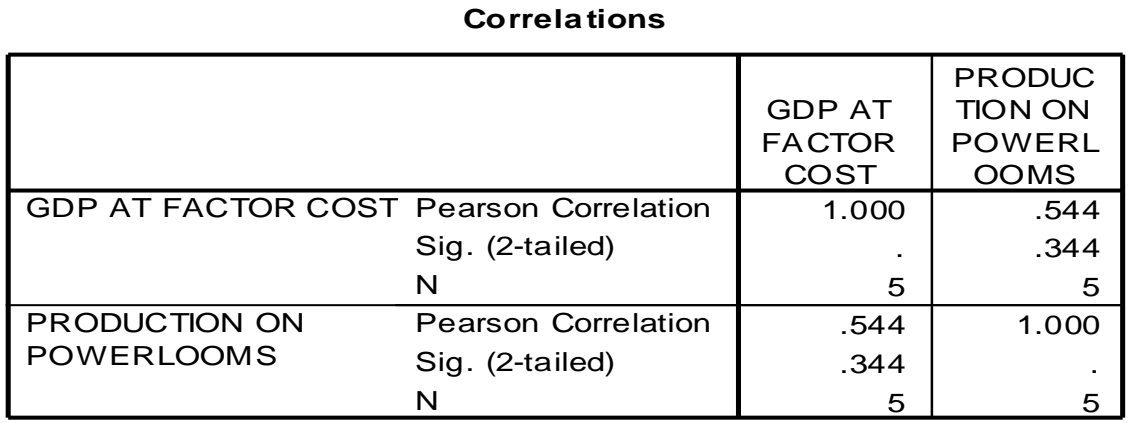

Karl Pearson's coefficient of correlation was carried out to understand the strength of relationship between number of powerlooms and the workers involved in the sector. From spss table 1 it is apparent that there is a very significant correlation between number of powerlooms and number of workers employed in the sector. It can be seen that correlation coefficient (r) equals to .999 which indicates a very positive relationship between number of powerlooms and employment generated.

From SPSS table 2, it is evident that production output and number of workers employed have a markedly significant relationship. As the output from powerlooms has increased over the years so has the created a positive impact on employment generation.

Similarly from SPSS table 3, it can be observed that the GDP at factor cost for the past 5 years when correlated with production on powerloom was found to be having a positive correlation. The analysis reflects that the .544 unit production in powerloom increases 1 unit of GDP.

\section{d) Suggestions}

After a poignant view of the decentralized powerloom sector and its ability to contribute to the Indian economy, it is imperative for the government to nurture this sector by framing policies which could propel the growth of the sector. Some of the suggestion that could be put forth from the study are:

1) The decentralized powerloom sector holds tremendous potential not only in terms of contribution to the GDP of India but also as a employment generator. Hence nurturing of the decentralized powerloom sector would be a pertinent move.

2) Expansion of powerloom service centers to all major clusters where more than 2000 looms are operating would be useful in countering most of the powerloom weavers problems.

3) Backward and Forward integration in the supply chain of fabric making needs to be explored. Joint cotton farming and Joint promotional forums could be devised and monitored by some government programs.

4) Providing support price for fluctuating yarn prices could be very handy in the revival of the sector.

5) Lenient view of the taxes imposed on the saris manufactured by powerlooms could spiral the demand for the products and make them more competitive in International markets. 


\section{References}

[1] Arif Anjum and D. V. Thakor, 2011, An Analytical Study of the Functioning and the Problems of the Powerloom Industry in Maharashtra with Special Reference to Malegaon Dist. Nashik, International Journal of Trade, Economics and Finance, Vol. 2, No. 3, June 2011.

[2] Summaiya R Shaikh \& Satish Dulange, 2013, A Study of Factors Affecting Productivity of Power Loom Industries, International Journal of Engineering Research \& Technology, Vol.2 Issue 12 (December - 2013)

[3] Jnana Ranjan Prusty and Sambit Mallick, 2013, Declining Powerloom Industry and Allied Technology Factors: A Sociological Study of Siminoi Powerloom Cluster in Odisha, Sociological society, E-journal, Vol.2, No.1, June, 2013

[4] Saravanan, K. A Ramya, 2015, A study on demographic profile and problems faced by the powerloom owners with special references to Coimbatore cluster, International Journal Of Research In commerce, IT \& Management, Vol. No.5,(205) Issue No.03 (March).

[5] Annual Report, Ministry of Textiles, 2015. 


\section{(Tables \& Figures)}

Table.1 showing various growth dimensions of decentralized powerlooms in India

\begin{tabular}{|l|l|l|l|l|l|l|}
\hline Year & $\begin{array}{l}\text { No. of } \\
\text { Units }\end{array}$ & $\begin{array}{l}\text { No. of of } \\
\text { powlooms }\end{array}$ & $\begin{array}{l}\text { No of } \\
\text { Powerloom } \\
\text { workers }\end{array}$ & $\begin{array}{l}\text { growth } \\
\text { percentage }\end{array}$ & $\begin{array}{l}\text { Total } \\
\text { production } \\
\text { (In mn sq } \\
\text { mts) }\end{array}$ & $\begin{array}{l}\text { production } \\
\text { on } \\
\text { powerloom } \\
\text { (In mn sq } \\
\text { mts) }\end{array}$ \\
\hline $2006-07$ & 440172 & $19,90,308$ & 4975770 & - & 53,389 & 32,879 \\
\hline $2007-08$ & 469563 & $21,06,370$ & 5265925 & $5.80 \%$ & 56,025 & 34,725 \\
\hline $2008-09$ & 494312 & $22,05,352$ & 5513380 & $4.70 \%$ & 54,966 & 33,648 \\
\hline $2009-10$ & 505260 & $22,46,474$ & 5616185 & $1.9 \%$ & 60,333 & 36,997 \\
\hline $2010-11$ & 517769 & $2,282,744$ & $5,729,157$ & $1.61 \%$ & 62,559 & 38,015 \\
\hline $2011-12$ & 519740 & $22,98,377$ & 5745942 & $0.68 \%$ & 60,453 & 37,445 \\
\hline $2012-13$ & 527806 & $23,47,249$ & 5868127 & $2.12 \%$ & 62,792 & 38,038 \\
\hline $2013-14$ & 530428 & 2367594 & 5918990 & $0.86 \%$ & 63,500 & 36,790 \\
\hline $2014-15$ & 543199 & $24,47,837$ & 6187500 & $3.38 \%$ & 65,097 & 37,566 \\
\hline $2015-16$ & 561134 & $25,11,453$ & 6278632 & $2.59 \%$ & 66,473 & 38,896 \\
\hline
\end{tabular}

Source- www.texmin.com Ministry of Textiles

Table 2: (Trend analysis for growth in number of powerlooms)

\begin{tabular}{|c|c|c|}
\hline Year & Powelooms & Trend \\
\hline $2006-07$ & 1990308 & 2062513 \\
\hline $2007-08$ & 2106370 & 2110004 \\
\hline $2008-09$ & 2205352 & 2157496 \\
\hline $2009-10$ & 2246474 & 2204987 \\
\hline $2010-11$ & 2282744 & 2252479 \\
\hline $2011-12$ & 2298377 & 2299971 \\
\hline $2012-13$ & 2347249 & 2347462 \\
\hline $2013-14$ & 2367594 & 2394954 \\
\hline $2014-15$ & 2447837 & 2442445 \\
\hline $2015-16$ & 2469938 & 2489937 \\
\hline $2016-17$ & Estimated & 2537429 \\
\hline $2017-18$ & Estimated & 2584920 \\
\hline $2018-19$ & Estimated & 2632412 \\
\hline $2019-20$ & Estimated & 2679903 \\
\hline $2020-21$ & Estimated & 2727395 \\
\hline
\end{tabular}

Source: Trend values are calculated by researcher 
Table 3. Trend analysis for growth in employment for powerloom workers in India

\begin{tabular}{|c|c|c|}
\hline Year & $\begin{array}{c}\text { No. of } \\
\text { workers }\end{array}$ & Trend \\
\hline $2006-07$ & 4975770 & 5137849 \\
\hline $2007-08$ & 5265925 & 5264985 \\
\hline $2008-09$ & 5513380 & 5392121 \\
\hline $2009-10$ & 5616185 & 5519257 \\
\hline $2010-11$ & 5729157 & 5646393 \\
\hline $2011-12$ & 5745942 & 5773529 \\
\hline $2012-13$ & 5868127 & 5900665 \\
\hline $2016-14$ & 5918990 & 6027801 \\
\hline $2014-15$ & 6187500 & 6154937 \\
\hline $2015-16$ & 6278632 & 6282073 \\
\hline $2016-17$ & Estimated & 6409209 \\
\hline $2017-18$ & Estimated & 6536345 \\
\hline $2018-19$ & Estimated & 6663481 \\
\hline $2019-20$ & Estimated & 6790617 \\
\hline $2020-21$ & Estimated & 6917753 \\
\hline
\end{tabular}

Source: Trend values are calculated by researcher

Table 4: Trend analysis for the growth of powerloom units in India

\begin{tabular}{|l|c|l|}
\hline Year & No. of Units & Trend \\
\hline $2006-07$ & 440172 & 460366.2 \\
\hline $2007-08$ & 469563 & 471604.4 \\
\hline $2008-09$ & 494312 & 482842.6 \\
\hline $2009-10$ & 505260 & 494080.8 \\
\hline & & \\
$2010-11$ & 517769 & 505319 \\
\hline $2011-12$ & 519740 & 516557.2 \\
\hline $2012-13$ & 527806 & 527795.4 \\
\hline $2016-14$ & 530428 & 539033.6 \\
\hline $2014-15$ & 543199 & 550271.8 \\
\hline $2015-16$ & 561134 & 561510 \\
\hline $2016-17$ & Estimated & 572748.2 \\
\hline $2017-18$ & Estimated & 583986.4 \\
\hline $2018-19$ & Estimated & 595224.6 \\
\hline $2019-20$ & Estimated & 606462.8 \\
\hline $2020-21$ & Estimated & 617701 \\
\hline
\end{tabular}

Source: Trend values are calculated by researcher 
Table 5. Trend analysis for production by powerloom sector in million sq $\mathrm{mts}$ in India

\begin{tabular}{|l|c|l|}
\hline Year & Trend \\
& Production & \\
\hline $2006-07$ & 32879 & 33982.41 \\
\hline $2007-08$ & 34725 & 34541.82 \\
\hline $2008-09$ & 33648 & 35101.24 \\
\hline $2009-10$ & 36997 & 35660.65 \\
\hline $201-11$ & 38015 & 36220.06 \\
\hline $2011-12$ & 37445 & 36779.47 \\
\hline $2012-13$ & 38038 & 37338.88 \\
\hline $2013-$ & & \\
14 & 36790 & 37898.3 \\
\hline $2014-15$ & 37566 & 38457.71 \\
\hline $2015-16$ & 38,896 & 39017.12 \\
\hline $2016-17$ & Estimated & 39576.53 \\
\hline $2017-18$ & Estimated & 40135.94 \\
\hline $2018-19$ & Estimated & 40695.36 \\
\hline $2019-20$ & Estimated & 41254.77 \\
\hline $2020-21$ & Estimated & 41814.18 \\
\hline
\end{tabular}

Source: Trend values are calculated by researcher

Figure 1

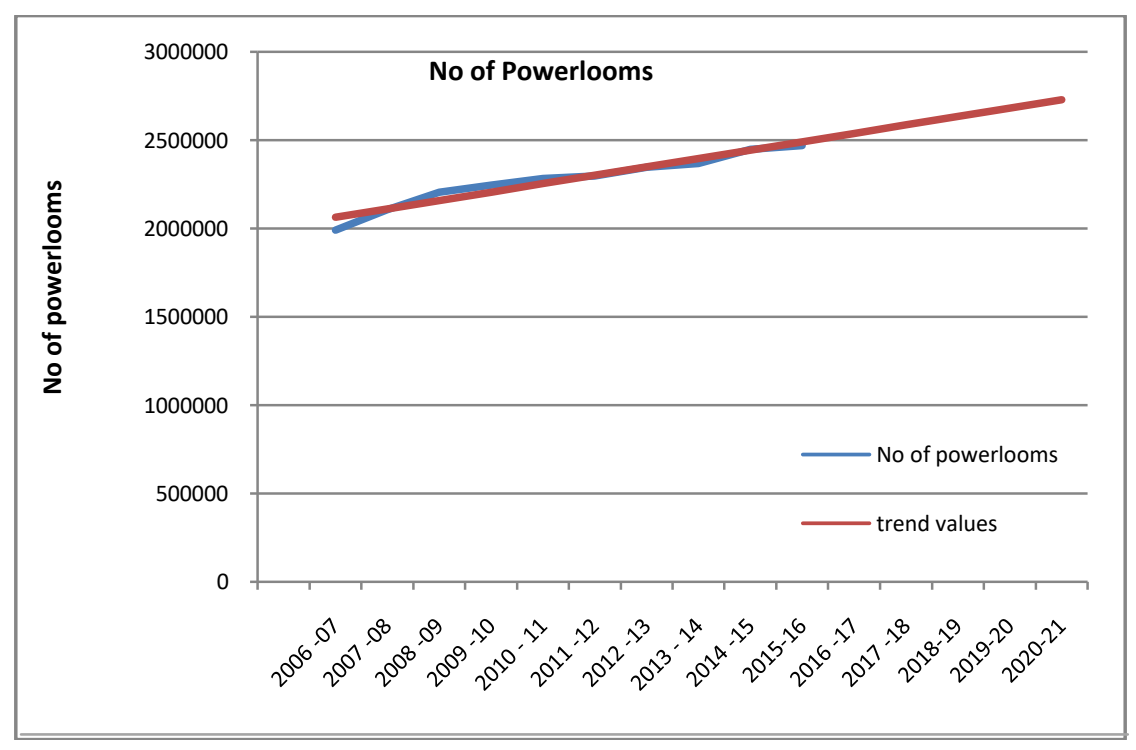

Source: Based on Annual Report-Ministry of Textiles 
Figure 2

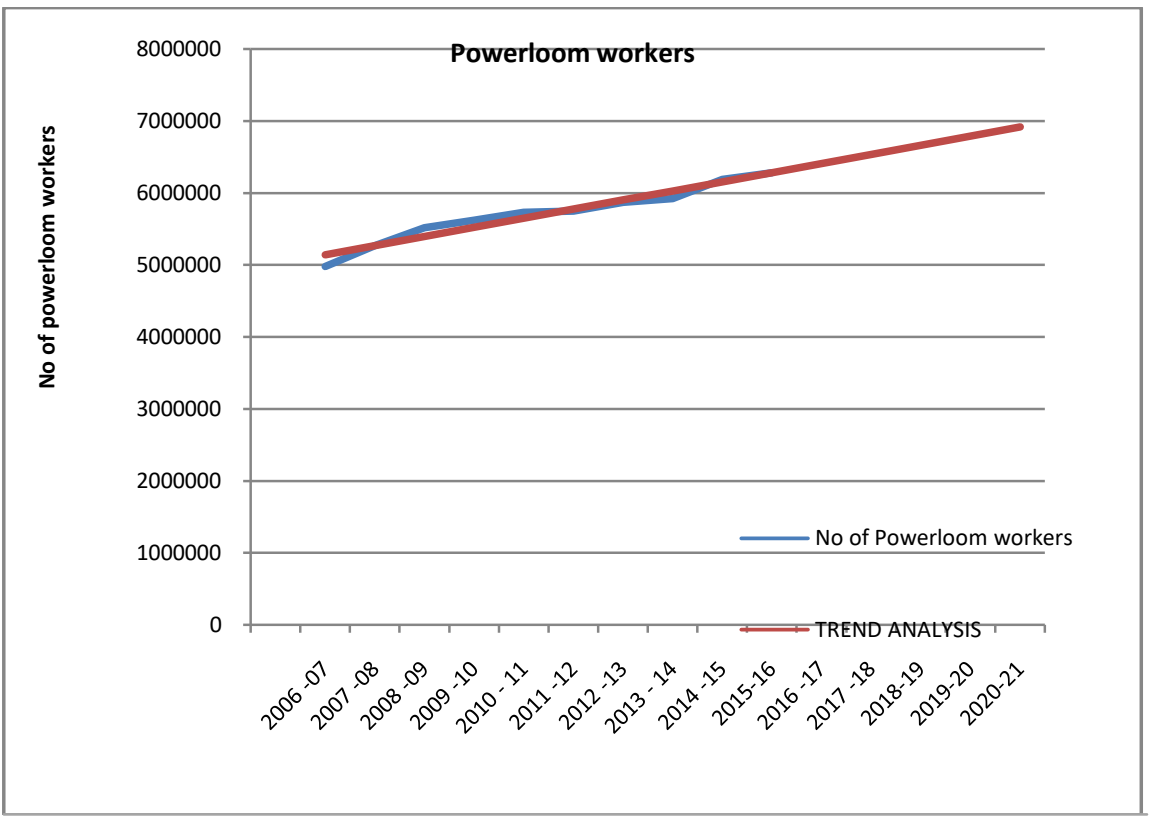

Source: Based on Annual Report-Ministry of Textiles

Figure 3

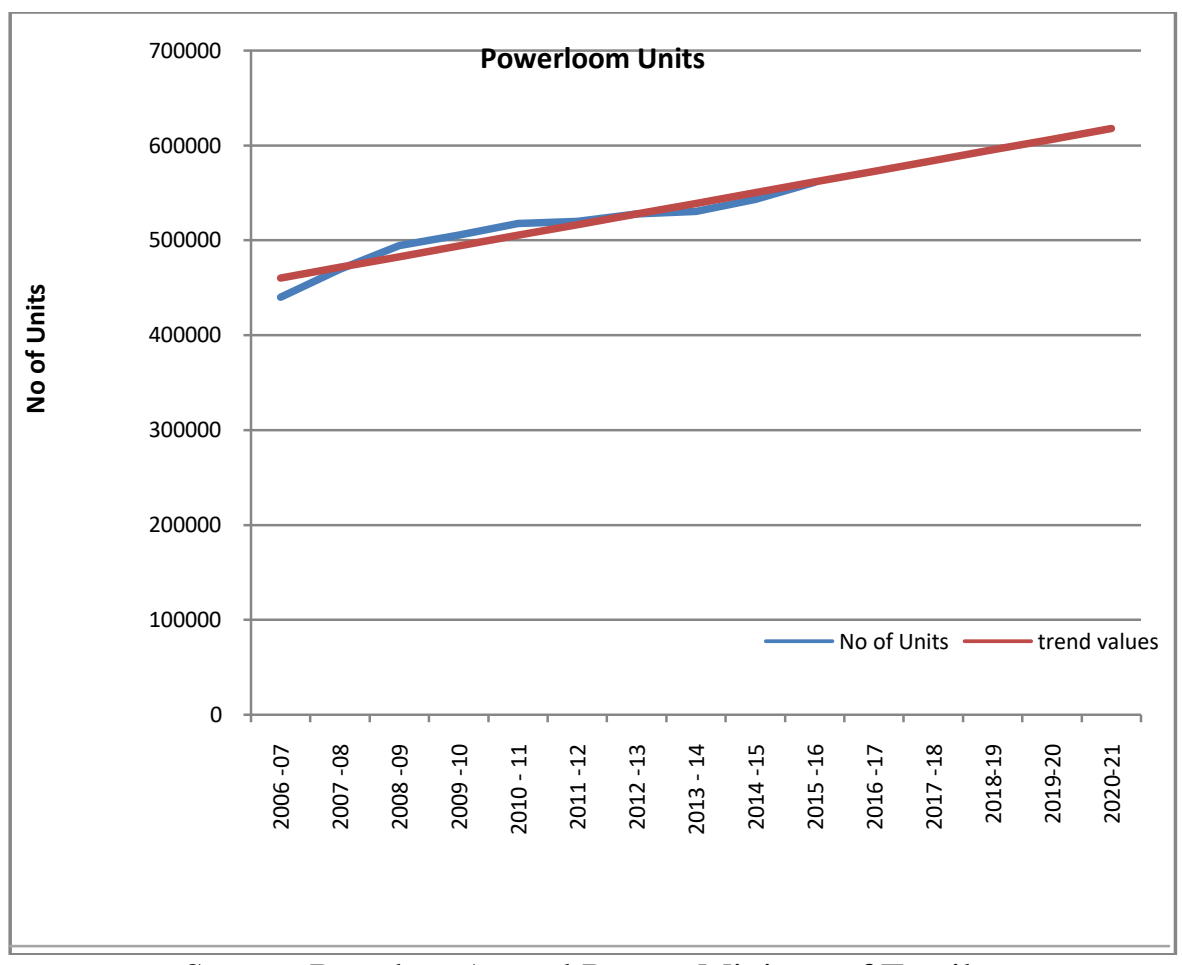

Source: Based on Annual Report-Ministry of Textiles 
Figure 4

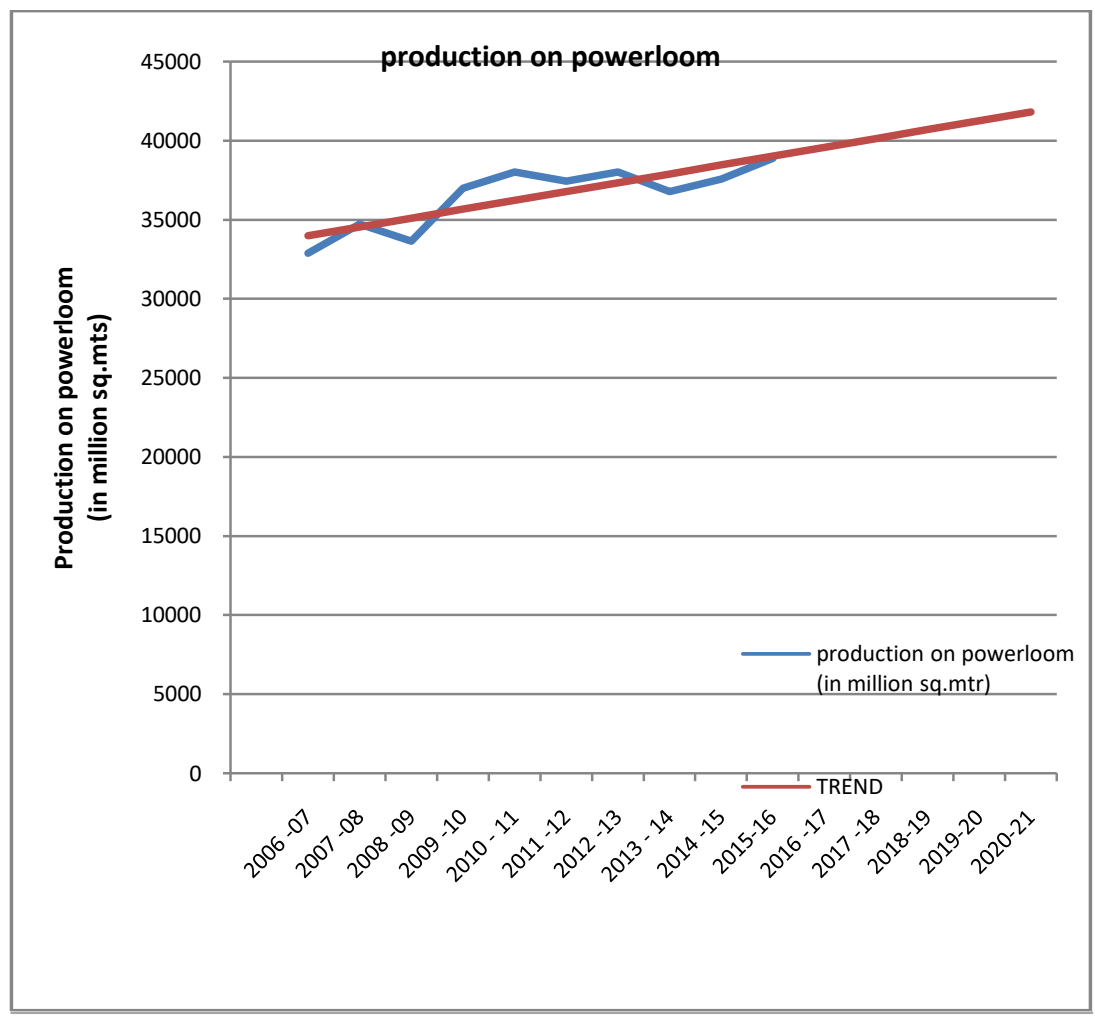

Source: Based on Annual Report-Ministry of Textiles 